University of South Carolina

Scholar Commons

$11-1979$

\title{
Concern for Policy Outputs as a Cue for Supreme Court Decisions on Certiorari
}

Donald R. Songer

University of South Carolina - Columbia, dsonger@sc.edu

Follow this and additional works at: https://scholarcommons.sc.edu/poli_facpub

Part of the Law Commons, and the Political Science Commons

\section{Publication Info}

Published in Journal of Politics, Volume 41, Issue 4, 1979, pages 1185-1194.

http://www.journalofpolitics.org/

(C) 1979 by Cambridge University Press for the Southern Political Science Association

This Article is brought to you by the Political Science, Department of at Scholar Commons. It has been accepted for inclusion in Faculty Publications by an authorized administrator of Scholar Commons. For more information, please contact digres@mailbox.sc.edu. 


\author{
Concern \\ for Policy Outputs \\ as a Cue for \\ Supreme Court \\ Decisions \\ on Certiorari
}

Donald R. Songer

\begin{abstract}
I
I CONTRAst To the large and growing literature on Supreme Court decision-making in cases decided with full opinions, relatively little has been written about the prior court decisions to grant or deny review on petitions for certiorari. Such a shortcoming may be due in part to the difficulty in obtaining the relevant empirical facts about the process of decision-making which the Supreme Court's "doctrine of secrecy" produces.

This lack of attention should not, however, be allowed to obscure the obvious policy significance of these decisions. In the past about 75 percent of all cases that went to oral argument reached the Supreme Court through petitions for certiorari. ${ }^{1}$ Certiorari decisions are thus a crucial part of the gatekeeping processes by which the justices determine which issues will be the subjects of Court output.

The justices on the Supreme Court have done little to aid scholars who seek to understand the process. Several studies have suggested that the official court criteria, contained in Rule 19, shed little light

1 Sheldon Goldman and Thomas P. Jahnige, The Federal Courts as a Political System (2nd ed.; New York: Harper and Row, 1976), 132.
\end{abstract}


on the subject. ${ }^{2}$ In addition, the Court frequently gives no reason for the denial of certiorari in a particular case and when it does purport to offer some explanation, the most frequent reasons given relate to the importance of the case. However, the Court rarely explains why a given case was considered "important."

An explanation of decisions on certiorari must begin by noting the large number of decisions which must be made in relatively short periods of time. One study found that at most each justice spends an average of 9.5 minutes per paid petition for certiorari and considerably less time on petitions filed in forma pauperis. ${ }^{3}$ Such time constraints obviously make detailed consideration of most petitions impossible.

The recognition of the lack of time justices have to study certiorari petitions combined with the belief that a substantial number of the petitions are frivolous led Joseph Tananhaus and associates to offer an explanation of certiorari decision-making based on cue theory. They hypothesized that judges used some method of separating those petitions which required serious attention from those that were frivolous and that a readily identifiable group of cues exists to serve this purpose. They suggested that the presence of any one of these cues will warn the justice that the petition deserves scrutiny, while if no cues are present a justice can safely discard the petition without further expenditure of time and energy. ${ }^{4}$

They hypothesized that petitions with no cues would be denied and those containing one or more cues would be studied carefully and between 25 percent and 43 percent of the petitions with cues would be granted. ${ }^{5}$ Three cues were found whose presence significantly increased the chances that a petition would be granted. Of the 1,226 petitions with one or more cues present, 27.5 percent were granted compared to the rate of 7.1 percent granted for the 1,372 petitions which contained no cues. ${ }^{6}$ Tanenhaus, et. al., con-

${ }^{2}$ A succinct summary of past studies which demonstrates the inadequacies of Rule 19 may be found in Joseph Tanenhaus, Marvin Schick, Matthew Muraskin, and Daniel Rosen, “The Supreme Court's Certiorari Jurisdiction: Cue Theory" in Glendon Schubert, ed., Judicial Decision-Making (Glencoe: Free Press, 1963), 113-115.

${ }^{3}$ Gerhard Casper and Richard A. Posner, The Workload of the Supreme Court (Chicago: American Bar Foundation, 1967), 65-66.

4 Tanenhaus, et. al., "Cue Theory," 118-120.

5 Ibid., 121.

6 Ibid., 126. 
cluded that of the three cues, the most important was the presence of the national government as the party seeking review. ${ }^{7}$

A subsequent study by S. Sidney Ulmer, et. al., confirmed the relative importance of the cue of the federal government as party and petitioner. In fact, when only cases actually discussed by the justices in conferences were used, the party cue was the only one of Tanenhaus' three cues which significantly increased the chances of certiorari being granted. ${ }^{8}$

The main factor which seems to be missing in cue theory as explicated by Tanenhaus, et, al., is any attention to the merits or the policy significance of the decision below in cases in which petitions for certiorari are filled. The belief that the policy values of judges influence their decisions in cases decided on the merits and that judges are concerned about the policy outputs of their courts is not a new idea to students of judicial behavior. ${ }^{9}$ In fact, as a recent textbook on the courts puts it, the "central hunch" of behavioral scholars since Pritchett is that, “. . . attitudes and values guide voting behavior and that the votes in specific cases-what the authorities actually do-are more important in revealing their attitudes and values than are the rationalizations they provide in their written opinions."10

Since justices appear to recognize the policy significance of their certiorari decisions, it would be reasonable to expect them to take the policy consequences of their actions into account when deciding whether or not to grant certiorari. Lawrence Baum suggests that although judges might pursue policy goals through any of several strategies, the most common method is likely to be an "error-correcting" strategy. That is, policy motivated judges would vote to grant certiorari whenever a lower court decision departed significantly from their preferred doctrinal position. ${ }^{11}$ Data from the California Supreme Courts seemed to be consistent with such a

7 Ibid., 127.

${ }^{8}$ S. Sidney Ulmer, William Hintze, Louise Kirklosky, "The Decision to Grant or Deny Certiorari: Further Consideration of Cue Theory," Law and Society Review, 6 (May, 1972), 640.

9 The best known example of such an approach is probably Glendon Schubert, Judicial Policy-Making (Glenview, Ill.: Scott, Foresman, 1965).

${ }^{10}$ Goldman and Jahnige, Federal Courts, 159-160.

11 Lawrence Baum, "Policy Goals in Judicial Gatekeeping: A Proximity Model of Discretionary Jurisdiction," American Journal of Political Science, 21 (1977), 14. 
strategy. ${ }^{12}$ Using votes on certiorari in the Supreme Court recorded by Justice Burton, Ulmer found a congruence between the votes of justices on certiorari and their votes on cases decided on the merits which is consistent with Baum's theory of an "error-correcting strategy. ${ }^{13}$ In a subsequent paper using the same date, Ulmer found that two liberal justices were more inclined to vote to grant certiorari when the petitioners had low status while two conservative justices were more prone to grant review to high state petitioners. ${ }^{14}$ Glendon Schubert's study of injured worker cases also led him to the conclusion that the justices were concerned with the policy consequences of the decision below when reviewing certiorari petitions. He maintained that the most reasonable explanation for his finding of a much higher rate of granting petitions from the workers than from their employers was the favortism of the Court for the claims of one class of litigants. ${ }^{15}$

If the scholars cited above are correct in their belief that judges are concerned about the policy consequences of their certiorari decisions, then cue theory leads to the expectation that the judges will search for some readily available cues which will enable them quickly to evaluate certiorari petitions from a policy perspective. To be adequate as such a cue the factor relied on must enable a judge to make a quick tentative judgment about whether the case below was decided "correctly" (that is, in conformity with the judge's own policy preferences) or whether the decision was in "error." If this cue indicated to the judge that the decision below. was in error, it could be taken as an indicator that the petition deserved more careful scrutiny, while if the cue indicated that the decision below was correct from his policy perspective and if no other cues were present, then the justice could safely discard the petition without further expenditure of time and energy.

For many cases, judges could make such tentative judgments about the "correctness" of the decision below by simply following the strategy used by many scholars to code decisions as "liberal" or

12 Ibid., 23-29.

${ }^{13} \mathrm{~S}$. Sidney Ulmer, "The Decision to Grant Certiorari as an Indicator to Decision 'On the Merits'," Polity, 4 (summer 1972), 429-447.

${ }^{14} \mathrm{~S}$. Sidney Ulmer, "Underdogs and Upperdogs: Litigant Status as a Factor in the Selection of Cases for Supreme Court Review" (paper presented at the 1976 meeting of the Southern Political Science Association, Atlanta, Georgia, November 4-6, 1976), 18-21.

15 Glendon Schubert, "Policy Without Law: An Extension of the Certiorari Game," Stanford Law Review, 14 (1962), 292. 
"conservative" in their research on judicial behavior. Such a coding technique usually relies on the nature of the winning and losing party in the case. The experience of the present author is that for many cases the decision can be classified as being either liberal or conservative with an examination of approximately one minute. This time expenditure is certainly consistent with the requirement of cue theory that the cue be "readily identifiable."

To test the hypothesis that such policy cues were being used by justices, all petitions for certiorari listed in U.S. Law Week for four years which dealt with economic policy were examined. It was expected that judges who were economic liberals would consider the policy cue to be present (i.e., they viewed the decision below to be incorrect from a policy perspective) if the losing party in the court below was a union or employee in a labor relations case; the national or state government in a case involving government regulation of the economy; the government in a corporate tax case or in an individual tax case involving estate tax, gift tax, or income on capital gains; or an injured worker in a suit to receive compensation for the injury. For an economic conservative, the policy cue was considered to be present if the court below supported the claims of the parties listed above (that is, the court below made a liberal decision).

Since the votes of individual justices on certiorari are not available except for the time period studied by Ulmer, time periods had to be found in which courts could be classified as relatively liberal or conservative on economic policy. ${ }^{16}$ There have been two periods in this century in which the ideological make-up of the Court has been significantly altered within five years by a single president who was both determined to change the Court and who was fortunate enough to be able to make four or five appointments within that period. These two periods were Franklin Roosevelt's second term (1937-40) and Richard Nixon's first term (1969-72).

The four years chosen for analysis were the years immediately before and after each of these two presidents had succeeded in reshaping the Court majority: 1935, 1941, 1967, 1972. The Court in 1935 and 1972 was classified as conservative on economic policy,

${ }^{16}$ For analysis of this data from Justice Burton's papers, see Ulmer, "Underdogs and Upperdogs"; Ulmer, "Decision to Grant Certiorari"; Ulmer, et. al., "Further Considerations of Cue Theory"; and S. Sidney Ulmer, "Supreme Court Justices as Strict and Not So Strict Constructionists: Some Implications," Law and Society Review, 8 (Fall 1973), 13-32. 


\section{TABLE 1}

Effect of the Presence of the Policy Cue for Decisions

to Grant Certiorari in Economic Cases:

1935, 1941, 1967, 1972 CoMBined

\begin{tabular}{ccc}
\hline Policy Cue & Certiorari Granted & Certiorari Denied \\
\hline Present & 114 & 184 \\
Absent & 41 & 294 \\
\hline \multicolumn{3}{c}{$N=633, \mathrm{x}^{2}=57.43, \mathrm{phi}=.091, \mathrm{p}<.001$} \\
& \multicolumn{2}{c}{ Percentage of Certiorari Petitions Granted } \\
\cline { 2 - 3 } & \multicolumn{2}{c}{ Cue Present $=38.3 \%$} \\
Cue Absent $=12.2 \%$
\end{tabular}

and in 1941 and 1967 was classified as liberal. ${ }^{17}$ For the two liberal courts, the policy cue was considered to be present if the decision in the court below was conservative. For the two conservative courts, the policy cue was considered present if the decision below was liberal.

The data used to test the proposition that policy cues were used by the justices in their screening of certiorari petitions is presented in Table 1. The data reveal that when the court below made a decision which the Supreme Court majority presumably would evaluate as in error from a policy perspective after a quick tentative evaluation, certiorari was granted 38.3 percent of the time. This figure is well within the theoretical expectations of Tanenhaus, et. al. ${ }^{18}$ On the other hand, when the policy cue was not present,

17 The change in the economic policy of the court from 1935 to 1941 is too well documented to require further explanation. For the classic work on the change, see C. Herman Pritchett, The Roosevelt Court: A Study in Judicial Politics and Values 1937-1947 (New York: Macmillan, 1948). The author's own tabulation, reported below, of the liberal and conservative decisions of the Supreme Court in economic cases decided with full opinions (all decisions with dissent and all unanimous reversals) in 1967 and 1972 supports the popular perception of the 1972 Burger Court as being more conservative than the 1967 Warren Court.

\begin{tabular}{lcc} 
& $\begin{array}{c}\text { liberal } \\
\text { decisions }\end{array}$ & $\begin{array}{c}\text { conservative } \\
\text { decisions }\end{array}$ \\
\cline { 3 - 3 } 1972 & 11 & 8 \\
1967 & 20 & 2 \\
\cline { 2 - 3 }$N=41, \mathrm{x}^{2}=6.15, \mathrm{p}<.02$
\end{tabular}

18 Tanenhaus, et. al., "Cue Theory," 121. 


\section{TABLE 2}

Effect of the Presence of the Government as Party Cue for Decisions to Grant Certiorari in Economic Cases: 1935, 1941, 1967, 1972 COMBINED

\begin{tabular}{ccc}
\hline Policy Cue & Certiorari Granted & Certiorari Denied \\
\hline Present & 64 & 35 \\
Absent & 91 & 443 \\
\hline
\end{tabular}

$$
N=633, \mathrm{x}^{2}=102.42, \mathrm{phi}=.161, \mathrm{p}<.001
$$

Percentage of Certiorari Petitions Granted

Cue Present $=64.6 \%$

Cue Absent $=17.0 \%$

certiorari was granted only 12.2 percent of the time. Since these differences are statistically significant at the .001 level of confidence, the hypothesis that policy cues are used by the justices initially appears to be confirmed.

However, the possibility that the relationship demonstrated above was caused by the presence of some other cues must be explored. Tanenhaus, et. al., found that the party cue (the federal government seeking review) had the greatest effect on the decision to grant certiorari. Table 2 demonstrates that the presence of the party cue was also strongly related to the decision to grant certiorari in the four Court terms included in this analysis. Therefore the party cue was chosen as the appropriate control variable for the relationship displayed in Table $1 .^{19}$

Table 3 presents the relationship between presence of the policy cue and the decision to grant or deny certiorari controlled by the presence or absence of the party cue. It may be seen that the presence of the policy cue is statistically significantly related to the tendency to grant certiorari at the .001 level of confidence for both those cases in which the party cue is present and those in which the party cue is absent. These results support the initial hypothesis that policy cues are in fact used by the justices.

Party and policy cues appear to have a reinforcing effect. When neither cue is present, the percentage of cases in which certiorari is

19 Of the other cues used by Tanenhaus, et. al., only the dissension cue is possibly present in the data used in this analysis. However, this cue was found to have much less effect on certiorari than either of the other cues. 


\section{TABLE 3}

Effect of the Presence of the Policy Cue for Decisions to Grant Certioraru in Economic Cases When Controlled for the Presence of the Party Cue

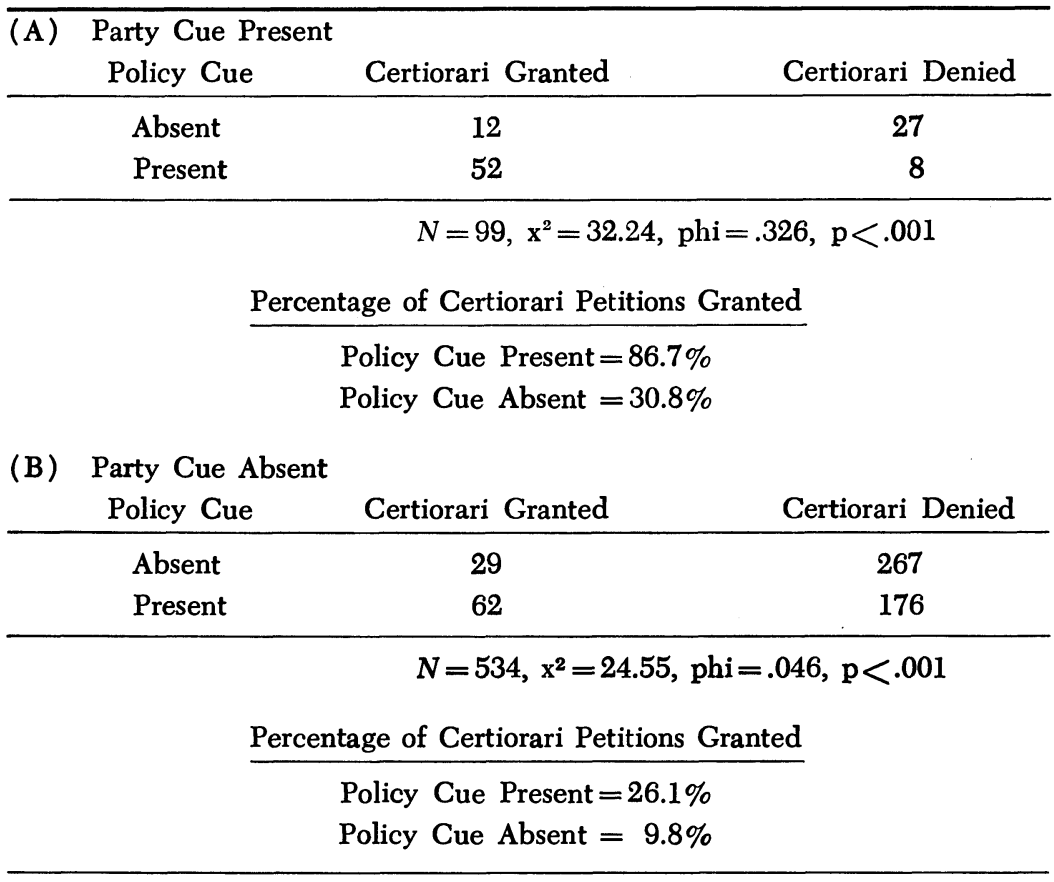

granted falls to 9.8 percent while, when both are present, it soars to the astounding acceptance rate of 86.7 percent. When only one of the cues is present the rate for granting certiorari assumed intermediate values.

One additional possibility remains to be explored. Since by definition all economic cases in which the national government seeks review (that is, those in which the party cues are present) are conservative decisions of the courts below, the relative strength of the party and policy cues may be affected by a differential tendency of the Court in all time periods to grant review to liberal and conservative decisions below.

To control for this possibility, the analysis of Table 3 was repeated with the sample of cases restricted to those in which the courts below made a conservative decision. The results are displayed in Table 4. 


\section{TABLE 4}

Effect of the Policy Cue for Decisions to Grant Certiorari in Economic Cases in Petitions from Conservative Decisions of the Courts BelowControlled for the Presence of the Party Cue

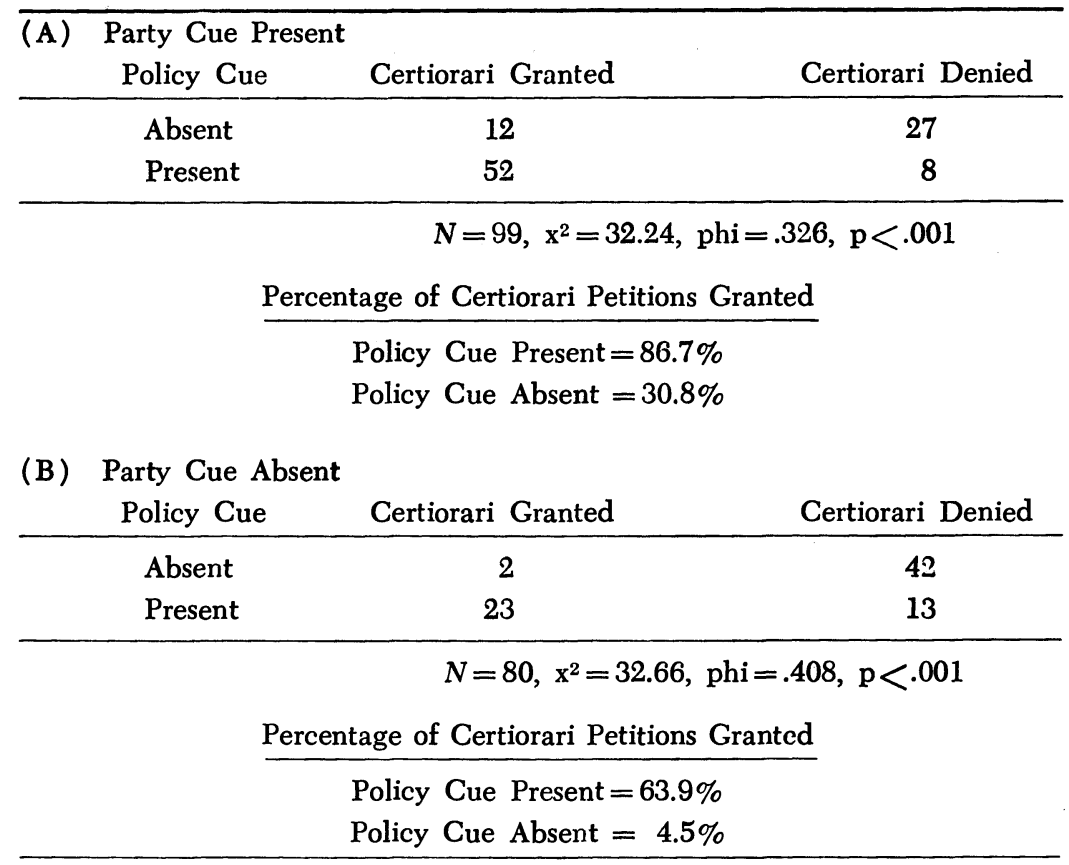

When only conservative decisions of the courts below are considered, the relationship between the presence of the policy cue and the decision to grant certiorari is very strong. When both the policy cue and the party cue are present, certiorari was granted in 86.7 percent of the cases. Perhaps more surprising, when the party cue is absent but the policy cue present, certiorari was still granted in 63.9 percent of the cases (compared to only 30.8 percent of the cases in which only the party cue was present). When neither cue was present, the success rate for the petitioners dropped to 4.5 percent.

The data presented above appear to be consistent with the cue theory of Supreme Court decision-making on certiorari petitions which was advanced by Tanenhaus and associates. They strongly suggest that in addition to the cues discovered by Tanenhaus, et. al., policy cues are used by the justices to determine which petitions 
deserve careful scrutiny. In fact the evidence suggests that when dealing with cases containing economic issues, policy cues are at least as important as the most important of the three cues discovered by Tanenhaus, et. al. The strength of association between the presence of the policy cue and the certiorari decision (as measured by the phi coefficient) when controlled by the presence or absence of the party cue was greater than the strength of association between the party cue and the certiorari decision when controlled by the policy cue. ${ }^{20}$ Although the differences between these measures of association are not large, they suggest that at least policy cues are of comparable importance to the party cue.

20 The phi value for the relationship between the party cue and the certiorari decision was .256 when the policy cue was also present and .041 when the policy cue was absent. 